\title{
Global warming triggers coral reef bleaching tipping point
}

\author{
This article belongs to Ambio's 50th Anniversary Collection. Theme: Climate change \\ impacts
}

Thomas J. F. Goreau, Raymond L. Hayes

Published online: 1 March 2021

\section{INTRODUCTION}

Coral reefs have among the most valuable ecosystem services per unit area and are most vulnerable of all ecosystems on the planet. The sudden outbreak of mass coral reef bleaching around the world in the 1980s was unprecedented, the first natural ecosystem threat from global warming, and an urgent alarm call for concerted efforts to reverse global warming. We have lost countless individual corals and entire reef tracts to mass bleaching and related stresses since our original Ambio paper (Goreau and Hayes 1994) was published, showing:

(1) mass coral reef bleaching could be accurately predicted worldwide from only the intensity and duration of satellite sea surface temperature data anomalies, with regard to the historical mean temperature in the warmest month, which we defined as the Coral Bleaching HotSpot,

(2) most reef corals bleach at $1{ }^{\circ} \mathrm{C}$ above the average temperature of the hottest month for one month at that location, and die if it is $2{ }^{\circ} \mathrm{C}$ above for a month or $1{ }^{\circ} \mathrm{C}$ above for two months (round numbers, sensitivity varies with species, and increases under combined temperature and light stress),

(3) coral reefs worldwide suddenly passed the tipping point of mass high temperature bleaching in the 1980s,

(4) extreme high temperature coral reef bleaching events are increasing in frequency,

(5) coral reef bleaching shows a pseudo El Niño (or La Niña) pattern where temperature correlates strongly

Disclaimer: The views and opinions expressed in this article are those of the authors. positively (or negatively) with the ENSO index. If global bleaching happens more often (as long as there are still corals left to bleach) corals will not have time to recover between bleaching episodes,

(6) coral mortality will accelerate while the most temperature-sensitive species die, and new diseases impact survivors (all new coral diseases spread fastest when it is hottest),

(7) coral reef ecosystems are the most vulnerable to increased temperature and will be the first to undergo functional extinction from global warming.

We defined the Coral Reef Bleaching HotSpot as the integrated temperature anomaly above the average temperature in the hottest month of the year, so it is a direct measure of all extreme surface ocean heat wave events. Figure 1 shows the September 262020 Goreau-Hayes Coral Reef Bleaching HotSpot map, posted daily by NOAA.

So far in 2020 our HotSpot method predicted mass coral bleaching events in Great Barrier Reef, Indonesia, India, Philippines, China, Taiwan, Okinawa, Palau, Guam, Federated States of Micronesia, and now the entire Caribbean Sea is in a HotSpot. Although we developed it for coral reef bleaching, the HotSpot map is the perfect tool for displaying extreme high temperature anomalies, including melting polar sea ice. It takes a $1^{\circ} \mathrm{C}$ (yellow in Fig. 1) anomaly for a month to cause coral reef bleaching, but these black Arctic Ocean anomalies in Fig. 1 have exceeded $5{ }^{\circ} \mathrm{C}$ ! They herald the impending demise of summer Arctic ice albedo, with positive albedo feedback causing more rapidly rising global temperatures in the future. There is little time left for either coral reefs or Arctic Ice if we do not reverse global warming immediately! 


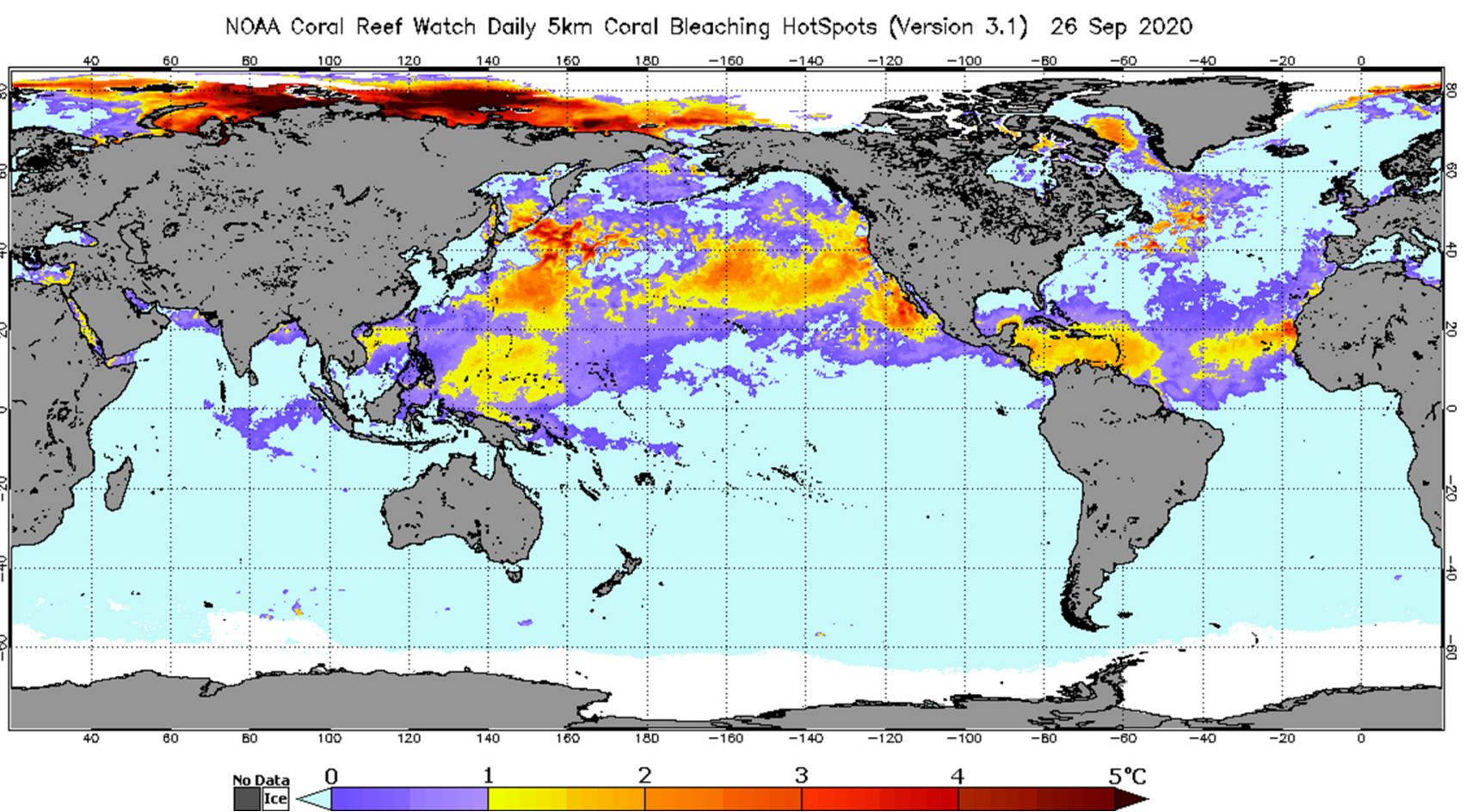

Fig. 1 Goreau-Hayes Coral Reef Bleaching Hot Spot Map from the NOAA Coral Reef Watch Daily $5 \mathrm{~km}$ coral bleaching record (coralreefwatch.noaa.gov/product $/ 5 \mathrm{~km}$ ), Accessed September 26, 2020. Ocean sites with SST anomalies range from $1{ }^{\circ} \mathrm{C}$ (yellow), $3{ }^{\circ} \mathrm{C}$ (red), and $>5{ }^{\circ} \mathrm{C}$ (black). Purple anomalies are $<1{ }^{\circ} \mathrm{C}$

Our Ambio paper concluded:

Large-scale funding for long-term research in these habitats is critically needed yet woefully inadequate in current international environmental protection and development policies. Protecting coral reefs for future generations may be the truest test of international commitments to sustainable development, because it places some of the most stringent constraints on doing the right thing for the environment (halting overfishing, reforesting coastal watersheds, providing complete tertiary sewage treatment, limiting climate change) at local, regional, and global scales simultaneously.

We expected that when scientific facts were known, governments of rich countries would do the right thing and act to save coral reefs from extinction by reducing atmospheric $\mathrm{CO}_{2}$ to safe levels, while funding poor countries to preserve and regenerate their coral reefs. Unfortunately, this never happened.

In July, 1991, National Oceanic and Atmospheric Administration (NOAA) supervisors denied that high temperature caused coral bleaching and withdrew previously granted authorization from the National Ocean Services to publish our analysis as a NOAA Technical report. Our work, that was to be co-authored with several NOAA investigators, was undervalued and discounted. The full history of how the information was effectively suppressed, and re-discovered decades later, is a story that continues today, and cannot be described here, since it would fill a large book.

Even though all its conclusions and predictions proved correct, our paper was ignored and rarely referenced. The core conclusions of the paper, sometimes lightly paraphrased, but often copied word for word without citation, came to be widely repeated in the literature by citing second, third or fourth-hand publications. The same happened to subsequent papers that greatly expanded the longterm coral reef global temperature database trends and revealed many important and unexpected global, regional, and local patterns, and global changes in ocean circulation (see reference list).

The impetus for our original study came from NOAA's satellite sea surface temperature database and government researchers who kindly gave us an opportunity to review their primary satellite data as it was released. We are greatly indebted to Jennifer Clarke, Al Strong, Dan Basta and Craig Robertson of NOAA for their cooperation and encouragement, and to coral reef researchers, especially Peter Glynn and Ernest Williams. However, resistance from government resulted in loss of time and hampered efforts to monitor and mitigate impacts of global warming on coral reefs by timely documentation of the natural stress responses observed in developing country coral reefs. Had 
Fig. 2 Four-year-old Biorock coral reef in Bali, Indonesia, grown at a site that had nothing but sand and dead coral rubble from the 1998 mass coral bleaching mortality event. Photo by EunJae Im

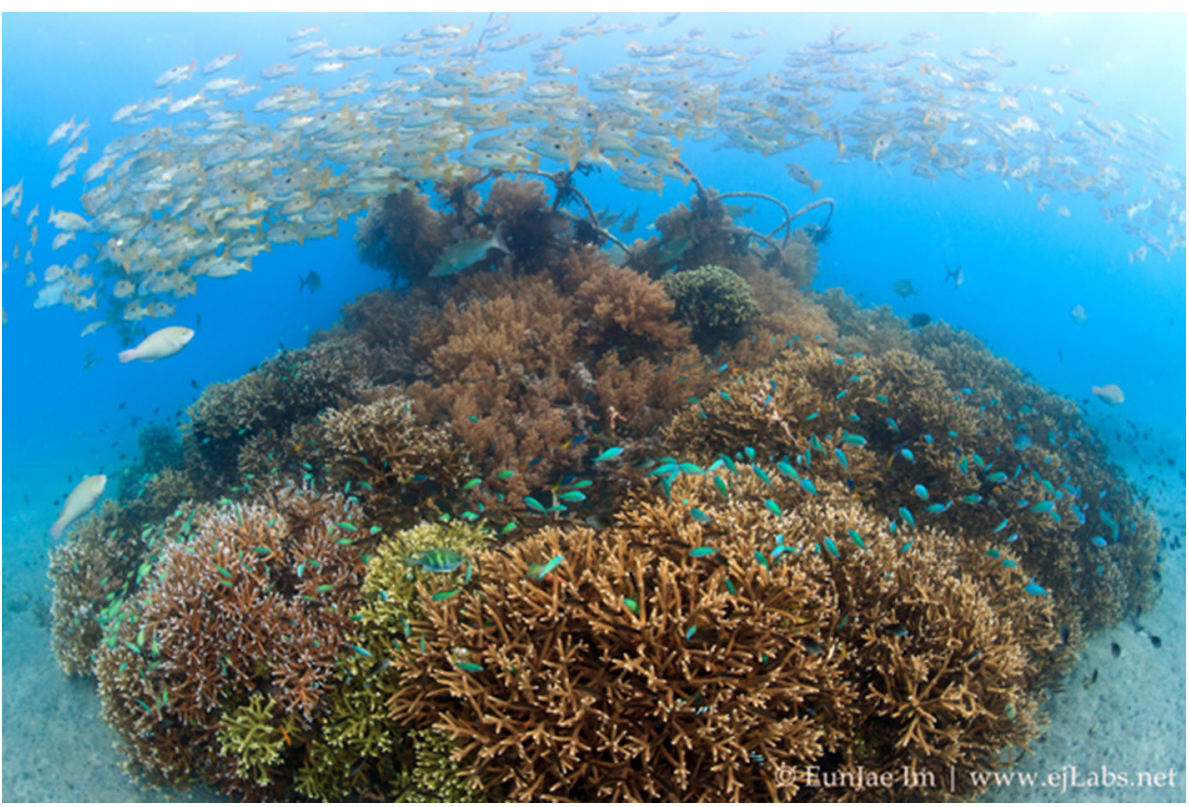

those studies been done as we recommended when the problem first appeared, the research community would have been better prepared to optimize reef recovery.

American and Australian funding agencies attempted to prove that anything else but high temperature triggered coral reef bleaching. Alternatives like sun screen lotions, ultraviolet light, and bacteria obfuscated the primary role of high temperature and confused the public and policy makers. Fortunes were spent chasing fads, promises of "super corals that don't bleach", "adaptive bleaching to expel bad symbionts and take on good ones", "engineering resilient reef management", blaming fishermen for reef degradation, etc. These distractions effectively diverted attention from global warming and the urgent need to reverse it if reefs were to be saved. Funding red herrings continued for three decades, and confirmed the negligible, minor, or at best, secondary role of other factors compared to high temperatures (which field data had already shown). Three decades that could have been put to good use building endogenous capacity of coral reef countries to regenerate their reefs were lost.

American and Australian government agencies like NOAA, the National Science Foundation, the Australian Institute of Marine Sciences, and the Great Barrier Reef Marine Protected Area allowed politics to guide science and let coral reefs die. Scientists taking their funding helped delaying tactics by obfuscating global warming impacts, denying field data, and claiming global warming was no threat to reefs. Governments still refuse to listen to scientists, resulting in failure of the United Nations
Framework Convention on Climate Change to protect the most climate threatened ecosystems. This effectively condemns coral reefs to extinction and threatens the survival of low island nations.

Prioritizing grant funding and implementation of real protection for coral reefs worldwide still lags hopelessly behind needs of small tropical islands and coastal nations. Marine Protected Areas cannot protect corals from bleaching, and dumping sewage and fertilizers in the sea persists, killing coral reefs, driven by economic pressures on impoverished local populations that vitally depend upon reef services. Climate change will accelerate until adequate funding is allocated to counteract global warming by reducing greenhouse gas concentrations that stress coral reef organisms (and interfere with functional integrity of other ecosystems), and by large scale regeneration of ecosystem services to remove and store carbon in biomass and soil.

There has been minimal progress towards enhancement of local reef management capacity in coral reef countries by documenting environmental history, understanding the causes of present changes, and preparing for future developments while coral reef science represents scientific tourism rather than local priorities. Developing country scientists most knowledgeable of long-term changes were marginalized by rich country funding establishments, delaying understanding of the urgency and novelty of coral reef bleaching, and preventing development of coral research capacity where most needed. Funding should go directly to coastal communities to regenerate marine 
ecosystems and to promote local capacity building in developing countries. Sweden is the only developed country doing so, but only in a handful of West Indian Ocean countries.

Contrastingly, Biorock electric Coral Arks, developed without funding in Jamaica and small islands around the world, increase coral health and reef biodiversity even through severe bleaching heatstroke, while regenerating fisheries and growing back severely eroded beaches naturally (Fig. 2). These methods provide an interim adaptation step that could save climatically vulnerable coral reefs, mangroves, sea grass, salt marsh, and coastlines, until $\mathrm{CO}_{2}$ is reduced to safe levels. This could be achieved in decades if governments followed biomass and soil carbon sequestration science.

If we lose coral reefs now to global warming, the geological record suggests it will be $3-4$ million years before new coral reefs can evolve. There is very little time left, so urgent unified global action to reduce coral stresses, while simultaneously growing corals with methods that greatly increase settlement, growth, survival, resistance to severe stress, and biodiversity, will be essential for survival of the majestic splendor of tropical coral reefs, and their incomparable ecosystem services.

2020 will be one of the worst coral bleaching years in history, yet it has been a LaNiña year, when it is cooler than normal. The next El Niño, which may already be starting, may deliver a final blow to coral reefs in many places.

\section{REFERENCES}

Goreau, T.J. 1990. Coral bleaching in Jamaica. Nature 343: 417.

Goreau, T.J. 1992. Bleaching and reef community change in Jamaica: 1951-1991. In Symposium on long term dynamics of coral reefs. American Zoologist 32: 683-695.

Goreau, T.J. 2014. Electrical stimulation greatly increases settlement, growth, survival, and stress resistance of marine organisms. Natural Resources 5: 527-537. https://doi.org/10.4236/nr.2014. 510048

Goreau, T.J., and R.L. Hayes. 1994. Coral bleaching and ocean "hot spots." Ambio 23: 176-180.

Goreau, T.J., and R.L. Hayes. 1995. A survey of coral reef bleaching in the South Central Pacific during 1994: Report to the
International Coral Reef Initiative, 201. Chappaqua, NY: Global Coral Reef Alliance.

Goreau, T.J., and R.L. Hayes. 2005a. Monitoring and calibrating sea surface temperature anomalies with satellite and in-situ data to study effects of weather extremes and climate changes on coral reefs. World Resources Review 17: 242-252.

Goreau, T.J., and R.L. Hayes. 2005b. Global coral reef bleaching and sea surface temperature trends from satellite-derived Hotspot analysis. World Resources Review 17: 254-293.

Goreau TJ, Trench RK (eds) Innovative Technologies for Marine Ecosystem Restoration. CRC Press, Boca Raton

Goreau, T.J., R.L. Hayes, J.W. Clark, D.J. Basta, and C.N. Robertson. 1993. Elevated sea surface temperatures correlate with Caribbean coral reef bleaching. In A global warming forum: Scientific, economic, and legal overview, ed. R.A. Geyer, 225-255. Boca Raton, FL: CRC Press.

Goreau, T.J., R.L. Hayes, and A.C. Strong. 1997. Tracking South Pacific coral reef bleaching by satellite and field observations. Proceeding of 8th International Coral Reef Symposium 2: 1491-1494.

Goreau, T.J., T. McClanahan, R. Hayes, and A. Strong. 2000. Conservation of coral reefs after the 1998 global bleaching event. Conservation Biology 14: 5-15.

Goreau, T.J., R.L. Hayes, and D. McAllister. 2005. Regional patterns of sea surface temperature rise: implications for global ocean circulation change and the future of coral reefs and fisheries. World Resources Review 17: 350-374.

Goreau, T.J.F., R.L Hayes, and E.H. Williams. 2018. We have already exceeded the upper temperature limit for coral reef ecosystems, which are dying at today's $\mathrm{CO}_{2}$ levels. United Nations Climate Change Talanoa Dialogue. Global Coral Reef Alliance White Paper. https://www.globalcoral.org/we-have-already-exceededthe-upper-temperature-limit-for-coral-reef-ecosystems-whichare-dying-at-todays-co2-levels/

Hayes, R.L., and T.J. Goreau. 1991. The tropical coral reef ecosystem as a harbinger of global warming. Proceeding of 2nd International conference on global warming. World Resources Review 3: 306-322.

Hayes, R.L., and T.J. Goreau. 2008. An analysis of satellite-derived sea surface temperatures from Caribbean and Atlantic reef sites, 1982-2003. Revista Biologia Tropical 56: 97-118.

Publisher's Note Springer Nature remains neutral with regard to jurisdictional claims in published maps and institutional affiliations.

Thomas J. F. Goreau $(\bowtie)$

Address: Global Coral Reef Alliance, 37 Pleasant Street, Cambridge, MA 02139, USA.

e-mail: goreau@globalcoral.org

Raymond L. Hayes

Address: Global Coral Reef Alliance, 37 Pleasant Street, Cambridge, MA 02139, USA.

e-mail: hayes.ray@gmail.com 